\title{
Recombinant Human Tissue Non-Specific Alkaline Phosphatase Successfully Counteracts Lipopolysaccharide Induced Sepsis in Mice
}

\author{
B. BENDER ${ }^{1}$, M. BARANYI ${ }^{1}$, A. KEREKES ${ }^{1}$, L. BODROGI ${ }^{1}$, R. BRANDS ${ }^{2}$, P. UHRIN ${ }^{3}$, \\ Z. BÖSZE ${ }^{1}$
}

${ }^{1}$ Rabbit Genome and Biomodel Group, NARIC-Agricultural Biotechnology Institute, Gödöllő, Hungary, ${ }^{2}$ Amrif BV, Wageningen, The Netherlands, ${ }^{3}$ Institute of Vascular Biology and Thrombosis Research, Center for Physiology and Pharmacology, Medical University of Vienna, Austria

Received October 10, 2014

Accepted January 7, 2015

On-line March 24, 2015

\section{Summary}

Sepsis is a life threatening condition that arises when the body's response to an infection injures its own tissues and organs. Sepsis can lead to shock, multiple organ failure and death especially if not recognized early and treated promptly. Molecular mechanisms underlying the systemic inflammatory response syndrome associated with sepsis are still not completely defined and most therapies developed to target the acute inflammatory component of the disease are insufficient. In this study we investigated a possibility of combating sepsis in a mouse model by intravenous treatment with recombinant human tissue nonspecific alkaline phosphatase (rhTNAP) derived from transgenic rabbit milk. We induced sepsis in mice by intraperitoneal injection of LPS and three hours later treated experimental group of mice by intravenous injection with rhTNAP derived from transgenic rabbits. Such treatment was proved to be physiologically effective in this model, as administration of recombinant rhTNAP successfully combated the decrease in body temperature and resulted in increased survival of mice (80 \% vs. $30 \%$ in a control group). In a control experiment, also the administration of bovine intestinal alkaline phosphatase by intravenous injection proved to be effective in increasing survival of mice treated with LPS. Altogether, present work demonstrates the redeeming effect of the recombinant tissue non-specific AP derived from milk of genetically modified rabbits in combating sepsis induced by LPS.

\section{Key words}

Tissue non-specific alkaline phosphatase • Lipopolysaccharides • Sepsis • Mice • Survival

\section{Corresponding author}

M. Baranyi, ImmunoGenes Kft., Hunor 20/A, H-2092 Budakeszi, Hungary. Fax: +36 0138121762. E-mail: baranyimari2@gmail.com

\section{Introduction}

Sepsis is defined by an overwhelming systemic inflammatory response syndrome to pathogens or pathogen associated molecular patterns. The most severe form of sepsis can result in septic shock characterized by multiple organ failure. Unfortunately, treatment strategies are limited and a number of promising attempts to combat this medical condition have failed in clinical trials (Riedemann et al. 2003, Angus and van der Poll 2013). Although thanks to intensive campaign the mortality in the last years in severe septic patients decreased in some countries to $30 \%$ (Levy et al. 2010), the availability of effective therapy is of critical importance in septic patients. Septic shock can be induced experimentally in response to endotoxin lipopolysaccharide (LPS), an essential component of the outer membrane of Gram negative bacteria, resulting in an uncontrolled release of pro-inflammatory mediators (Heine et al. 2001, Uhrin et al. 2013).

In our study, we investigated a possibility of combating sepsis in a LPS-induced murine model of sepsis, by treatment of mice with recombinant human tissue non-specific alkaline phosphatase (rhTNAP) derived from milk of transgenic rabbits previously generated in our laboratory (Bodrogi et al. 2006). 
Tissue-nonspecific alkaline phosphatase (TNAP) is a member of a family of alkaline phosphatases (APs) consisting of at least three additional, distinct but related alkaline phosphatases: intestinal, placental and placentallike (ALPPL2). TNAP is expressed in a variety of tissues and cells including bone, cartilage, liver and kidney (Hoshi et al. 1997). In humans, genetic deficiency of TNAP results in hypophosphatasia, a disorder of bone mineralization (Henthorn et al. 1992). Inactivation of TNAP in knockout mice causes growth impairment and development of epileptic seizures due to defective metabolism of vitamin $\mathrm{B}_{6}$ (Waymire et al. 1995, Narisawa et al. 1997).

Members of the group of APs were shown to exhibit a detoxifying effect on LPS through its dephosphorylation in vitro (Poelstra et al. 1997a,b) and in vivo (Koyama et al. 2002). Subsequently, usage of AP derived from calf intestine or human placenta was demonstrated to be beneficial in sepsis models attenuating LPS toxicity (Bentala et al. 2002, Beumer et al. 2003, Verweij et al. 2004, Su et al. 2006). In our study we show now the redeeming effect of administration of the rhTNAP in combating sepsis in a LPS-induced model of sepsis in mice.

\section{Methods}

\section{Partial purification of rhTNAP and endotoxin determination}

Rabbit milk samples containing rhTNAP were obtained from homozygous transgenic females (Bodrogi et al. 2006). Control samples were derived from milk of non-transgenic females. Briefly, animals were separated over night from their pups, i.p. injected with oxytocin (2 IU, Kela N.V., Belgium) and milked. After centrifugation of fresh milk samples for $20 \mathrm{~min}$ at $800 \mathrm{~g}$ and $4{ }^{\circ} \mathrm{C}$, the upper fat fraction was collected and resuspended in milliQ water. To extract rhTNAP from milk fat globule membranes, a single phase extraction method previously elaborated for obtaining of AP was used (Ahn and Snow 1993). Briefly, n-butanol in a final concentration of $10 \%(\mathrm{v} / \mathrm{v})$ was used for the extraction of fat globule membranes binding in the case of transgenic milk the rhTNAP. The samples were kept shaking for $30 \mathrm{~min}$ at room temperature and centrifuged for $90 \mathrm{~min}$ at $4{ }^{\circ} \mathrm{C}$ and 100,000 g. Water phase containing the rhTNAP fraction was collected, aliquoted, freeze-dried and redissolved in sterile $0.9 \%(\mathrm{w} / \mathrm{v}) \mathrm{NaCl}$. This procedure yielded rhTNAP at concentration of 7.8-11.7 $\mathrm{U}$ per $1 \mathrm{ml}$ of transgenic rabbit milk. Some aliquots of milk extracts were also re-dissolved in water and used for testing for contamination with endotoxin, using Limulus Amoebocyte Lysate (LAL) Assay (Endotoxin Detection Service, Hyglos GmbH, Regensburg, Germany).

\section{SDS-PAGE and determination of AP activity}

Milk extracts derived from transgenic and nontransgenic rabbits were examined on $10 \%$ gels on their residual protein content and AP activity. Protein content was estimated using SDS-PAGE gels and Coomassie Brillant Blue-R (PageBlue, Vilnius, Lithuania) and silver staining (Sigma, St. Louis, MO). AP activity in protein extracts was determined by $10 \%$ native-PAGE gels by staining with a mixture of 5-bromo-4-chloro-3-indolyl-1phosphate (BCIP) and nitro blue tetrazolium (NBT) (Western Blue Stabilized Substrate for Alkaline Phosphatase, Promega, Madison WI, USA).

\section{Animals and experimental design}

Two months old male Balb/c mice (obtained from Harlan, Wobe Ltd., Hungary) were subjected to LPS-induced model of sepsis. The animals were divided into two groups consisting of 10 mice (designated as LPS+rhTNAP and as LPS+control group). Both groups were treated by i.p. injection of LPS (Escherichia coli 0111:B4, L5293 Sigma, St. Louis MO, USA, $15 \mu \mathrm{g} / \mathrm{g}$ body weight, dissolved in $200 \mu \mathrm{l}$ of $0.9 \% \mathrm{NaCl}$ ). Three hours later animals in a group LPS+rhTNAP received i.v. injected 9 units of rhTNAP, dissolved in $500 \mu$ of $0.9 \%$ $(\mathrm{w} / \mathrm{v}) \mathrm{NaCl}$. Mice in the LPS+control group were treated by injecting of milk extract dissolved in $500 \mu \mathrm{l}$ of $0.9 \%$ (w/v) $\mathrm{NaCl}$ derived from non-transgenic rabbit milk and lacking rhTNAP activity. Body temperature of mice was measured by rectal thermometry immediately before the LPS injection, and at time points $3 \mathrm{~h}$ and $21 \mathrm{~h}$ later. At these time points, $50 \mu \mathrm{l}$ of blood were collected by orbital punction into tubes without anticoagulants to determine AP activity. Survival of mice was monitored for at least up to 7 days.

In a subsequent experiment three groups of two months old Balb/c male mice consisting of 10 mice per group were studied. Mice were treated with i.p. LPS injection followed by i.v. injection of 9 units of rhTNAP, or of 9 units of bovine intestinal alkaline phosphatase (bIAP, Alloksys Life Sciences B.V., Bunnik, The Netherlands, dissolved in $500 \mu \mathrm{l}$ of $0.9 \%$ (w/v) $\mathrm{NaCl}$ ) or of control milk fraction. Also in this experiment survival of mice was monitored for up to 7 days. 
(a)

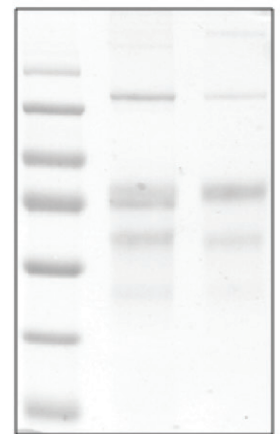

$1 \quad 2 \quad 3$ (b)

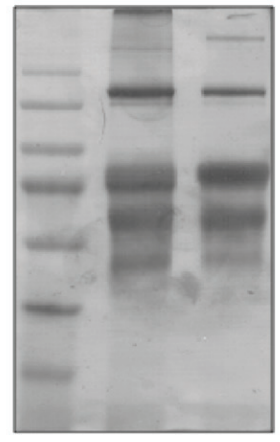

$\begin{array}{lll}1 & 2 & 3\end{array}$ (c)

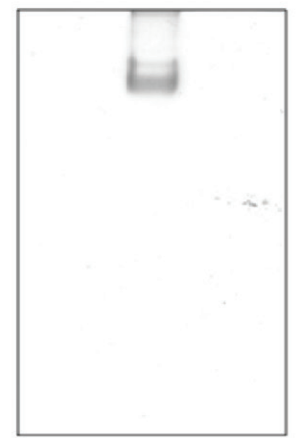

123 (d)

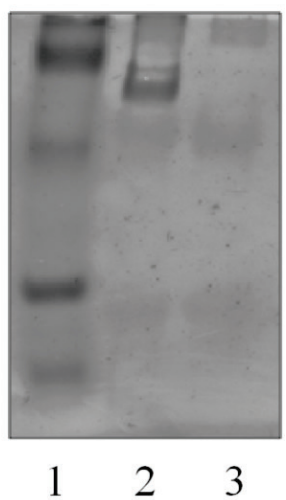

Fig. 1. Gel electrophoresis of protein extracts derived from transgenic and non-transgenic rabbit milk. SDS-PAGE with (a), Coomassie staining and (b), silver staining to determine residual total protein content. (c), Native-PAGE and BCIP/NBT treatment to confirm AP activity in protein extracts derived from transgenic rabbit milk. (d), Coomassie staining after native-PAGE and BCIP/NBT treatment to analyse residual protein content. Lane 1: molecular weight markers, from top to bottom: (a and b), $170 \mathrm{kDa}, 130 \mathrm{kDa}, 100 \mathrm{kDa}$, 70 kDa, 55 kDa, 35 kDa, 25 kDa; (c and d), 240 kDa, 160 kDa, 67 kDa, 45 kDa, 25 kDa. Lane 2: rhTNAP extract from transgenic rabbit milk. Lane 3: AP extract from control rabbit milk

All animal experimental protocols complied with the European Guidelines on Laboratory Animal Care and were performed upon the approval of the Directorate for Animal Care Committee (Reg. number: 22.1/1911/2007).

\section{Determination of AP activity}

The AP activity of the partially purified protein fractions and of the serum samples was determined with a $p$-nitrophenol-phosphate (pNPP) chromogenic based method (Cyboron and Wuthier 1981). Here, the colorless pNPP was hydrolyzed by AP at room temperature and at pH 9.6 forming yellow free $p$-nitrophenol. The change in optical density at $405 \mathrm{~nm}$ per unit time was indicative of AP activity, where one unit of activity is defined as $1 \mu \mathrm{mol}$ of substrate hydrolyzed per min using the molar absorption coefficient $(\varepsilon)$ of $1.87 \mathrm{~cm}^{2} / \mu$ mole of $p$ nitrophenol at $405 \mathrm{~nm}$. Volume activity (U/ml) was determined by measuring the change in absorbance per min over the linear portion of the curve and using this value in the following calculation:

Volume activity $\mathrm{U} / \mathrm{ml}=\frac{\left(\Delta \mathrm{E}_{405 \mathrm{~nm}} / \mathrm{min}\right) \times \mathrm{V}_{\mathrm{t}}}{\mathrm{V}_{\mathrm{s}} \mathrm{x} \varepsilon} \times$ dilution factor

where $V_{t}$ is the final volume of reaction mix $(\mathrm{ml})$, and $V_{s}$ is the sample volume $(\mathrm{ml})$.

\section{Statistical analysis}

Values are expressed as mean \pm standard deviation. Data were analyzed by GraphPad Prism 5 software. For survival analysis we performed log rank tests with Kaplan-Meier curves. Criteria for significance for all experiments were $\mathrm{p}<0.05$.

\section{Results}

Characterization of protein extracts derived from transgenic and non-transgenic rabbit milk by gel electrophoresis, determination of AP activity and of endotoxin content

We examined protein content and AP activity in milk extracts derived from milk of transgenic and control non-transgenic rabbits in SDS-PAGE gels by Coomassie (Fig. 1a) and silver staining (Fig. 1b). Subsequently, we proved the AP activity in milk extracts derived from transgenic rabbits, contrary to those derived from control milk samples, by treatment of gels with a mixture of BCIP and NBT (Fig. 1c) and estimated residual protein by Coomassie staining (Fig. 1d).

We further quantified the AP activity in samples derived from milk of transgenic rabbits by spectrophotometry using chromogenic substrate. Based on the outcome of these analyses, we diluted samples to achieve the AP activity of $9 \mathrm{U}$ per $500 \mu \mathrm{l}$. Control samples derived from milk of non-transgenic rabbits were diluted in a similar way under the consideration of the residual protein content (data not shown).

As the contamination of samples derived from milk with excessive endotoxin LPS could influence the outcome of the in vivo model of sepsis, we determined endotoxin levels by LAL assay. Indeed, levels of endotoxin in these extracts were very low (7.1 pg and 
$5.3 \mathrm{pg}$ in $500 \mu \mathrm{l}$ volume used for i.v. injection, respectively). Altogether, we can conclude that the biological effects reported in our study are attributed to the enzymatic activity of the rhTNAP protein and not to relatively minor contamination of probes with endotoxin.

Pilot experiment to determine the effective amount of rhTNAP and the optimal time of administration

We treated Balb/c mice ( 3 mice per group) with $15 \mu \mathrm{g} / \mathrm{g}$ LPS (i.p.), followed by the i.v. injection of the milk extracts containing 3,6 and 9 units of rhTNAP at 1 , 2, 3 and $4 \mathrm{~h}$ after LPS injection. Based on the outcome of this pilot experiment (data not shown), we selected usage of 9 units of rhTNAP for treatment of mice, $3 \mathrm{~h}$ after the LPS injection. As described below, next we determined AP activity levels in serum of mice upon such treatment and monitored body temperature and mice survival.

\section{AP activity in blood serum}

Intravenous injection of 9 units of rhTNAP resulted in relatively high levels of AP activity detected in the serum of blood samples taken $5 \mathrm{~min}$ after administration of rhTNAP (Fig. 2). Since the injection of the recombinant protein through the tail vein is a delicate procedure (and not reproducible with $100 \%$ accuracy), the levels of AP in their serum ranged between 1.38 to $5.11 \mathrm{U} / \mathrm{ml}$. At $21 \mathrm{~h}$ after administration, AP activity levels in serum decreased in all animals to the background levels (Fig. 2), consistent with the observed plasma elimination curves of calf intestinal phosphatase determined in a previous study (Beumer et al. 2003).

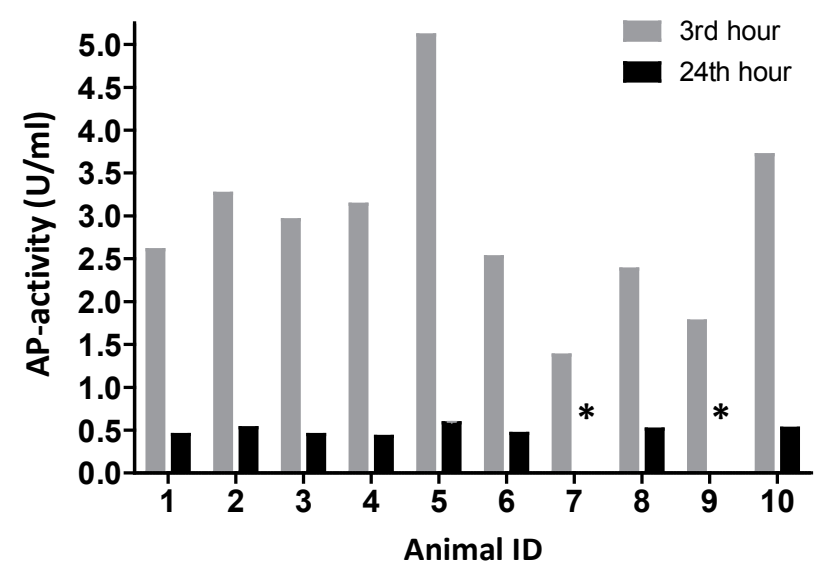

Fig. 2. Alkaline phosphatase activity in blood serum upon rhTNAP injection. Mice were i.p. injected with LPS and $3 \mathrm{~h}$ later treated by i.v. injection of rhTNAP or control fraction. AP activity was measured in serum derived from blood obtained 5 min after rhTNAP administration and $21 \mathrm{~h}$ later. Animals labeled with asterisk died within 10 to $24 \mathrm{~h}$ upon LPS administration.

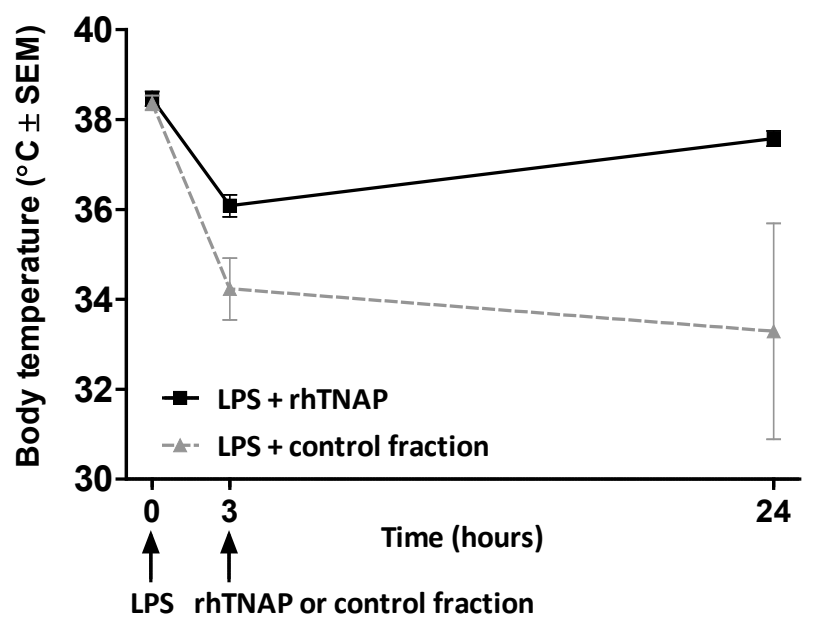

Fig. 3. Effect of LPS and rhTNAP on body temperature in mice. Mice were i.p. injected with LPS and $3 \mathrm{~h}$ later treated by i.v. injection of rhTNAP or control fraction. rhTNAP treatment normalized body temperature of mice $(p<0.05)$.

\section{Body temperature}

LPS injection in control group of mice, similarly as in the interleukin beta-1 deficient mouse model (Kozak et al. 1995) and in E. coli induced sepsis (Beumer et al. 2003), decreased body temperature of mice. Importantly, however, the temperature in a group of mice treated with rhTNAP reached at $24 \mathrm{~h}$ after LPS injection, upon an initial decrease, normal levels indicating beneficial effect of treatment of the animals with rhTNAP (Fig. 3).



Fig. 4. Survival of mice within $48 \mathrm{~h}$ after LPS injection and upon rhTNAP administration. Mice were i.p. injected with LPS and $3 \mathrm{~h}$ later treated by i.v. injection of rhTNAP or control fraction. rhTNAP treatment significantly $(p<0.05)$ increased survival of mice.

\section{Increased survival of animals treated with rhTNAP}

The above treatment of mice with 9 units of rhTNAP applied $3 \mathrm{~h}$ upon LPS injection dramatically 
increased survival of mice (Fig. 4), as only 2 of 10 animals died in this group, contrary to a control group of mice treated with a control fraction derived from nontransgenic rabbits (7 out of 10 mice died within 10-30 h after LPS administration). Indeed, the two animals in LPS + rhTNAP group that died had the lowest AP activity levels in their blood upon rhTNAP injection (mice with ID 7 and 9, and levels 1.38 and $1.77 \mathrm{U} / \mathrm{ml}$, respectively, Fig. 2), further pointing to the protective effect of circulating AP regarding the survival. Mice that did not die within $48 \mathrm{~h}$ permanently survived the experiment, as revealed by monitoring for at least 7 following days.

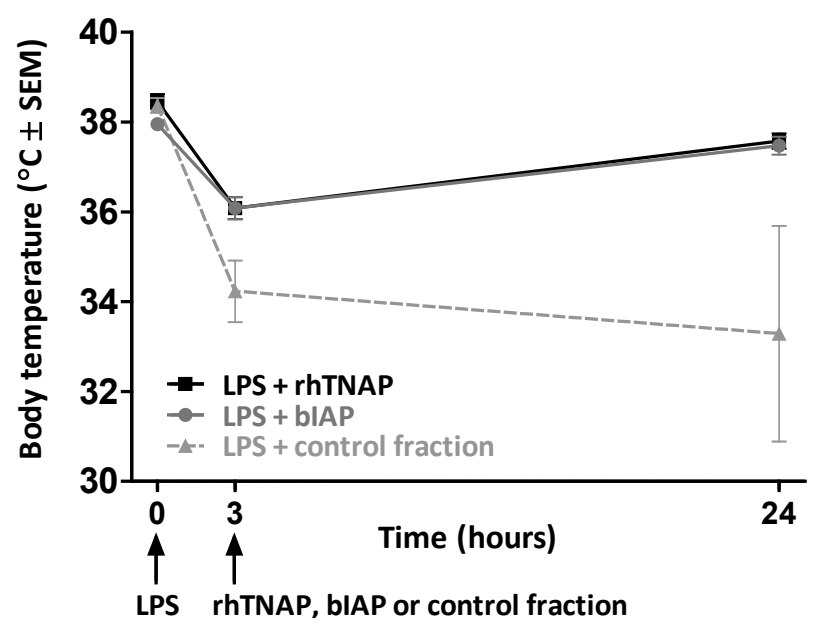

Fig. 5. Effect of LPS and rhTNAP or bIAP on body temperature in mice. Mice were i.p. injected with LPS and $3 \mathrm{~h}$ later treated by i.v. injection of rhTNAP, bIAP or control fraction. Both, rhTNAP, and bIAP treatment normalized body temperature of mice $(p<0.05)$.

Increased survival of animals treated with bovine intestinal alkaline phosphatase (bIAP)

To underline that the beneficial effects of rhTNAP in combating of LPS-induced decreased body temperature and mortality are indeed due to AP activity, in additional control experiment we treated 10 mice, $3 \mathrm{~h}$ after LPS injection, with 9 units of bIAP, in parallel with 10 mice treated with 9 units of rhTNAP and 10 animals treated with control extracts derived from non-transgenic rabbit milk. Indeed, both types of APs, the bIAP and rhTNAP, similarly restored body temperature to normal levels within $21 \mathrm{~h}$ (Fig. 5). Both type of treatment also increases survival, as in a group of mice treated with bIAP and rhTNAP 3 and 2 mice died, respectively, compared to 7 mice in a control group (Fig. 6). Altogether, these results demonstrate the beneficial effects of treatment with APs in a LPS induced model of sepsis.

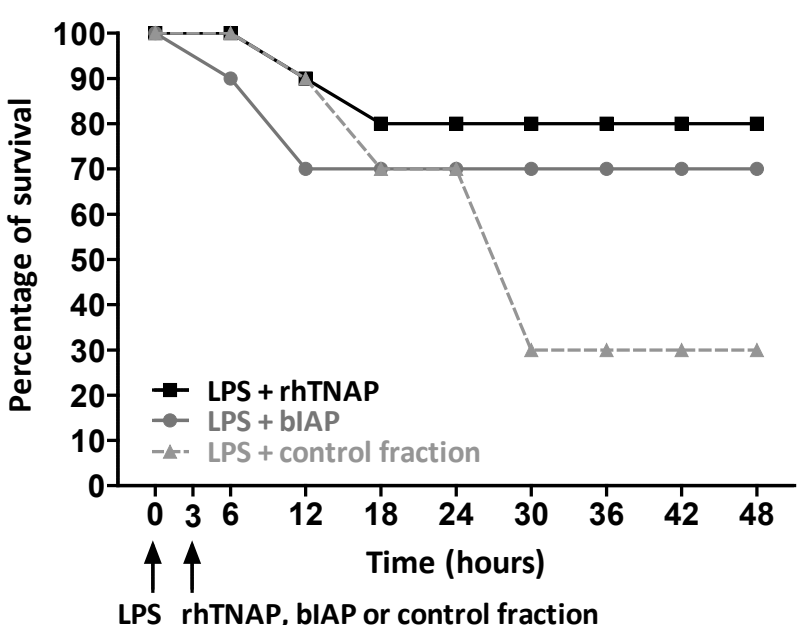

Fig. 6. Survival of mice within $48 \mathrm{~h}$ after LPS injection and upon rhTNAP or bIAP administration. Mice were i.p. injected with LPS, followed by i.v. injection with rhTNAP, bIAP or control fraction $3 \mathrm{~h}$ later. Both, rhTNAP and bIAP treatment significantly $(\mathrm{p}<0.05)$ increased survival of mice.

\section{Discussion}

A number of strategies have been explored to treat life-threatening complications of sepsis in patients (Lam et al. 2013). Detoxification of LPS itself represents a promising strategy to this problem (Schulte et al. 2013). It was Poelstra et al. (1997a,b) who first suggested the role of APs in the protection against endotoxin insult typical for Gram negative bacteria by showing that LPS is a substrate for AP. In their subsequent study the authors demonstrated the capability of human placental AP to detoxify LPS, which was achieved by dephosphorylation of its lipid A moiety (Bentala et al. 2002). When mice received human placental AP immediately after the LPS challenge, the survival rate was $100 \%$ compared to $57 \%$ in a control group (Bentala et al. 2002). Beneficial effect of using human placental AP was also shown in sepsis model in mice treated with E. coli (Verweij et al. 2004), and of intestinal AP in a sepsis model induced by feces injection in sheep ( $\mathrm{Su}$ et al. 2006). Usage of bovine and calf intestinal alkaline phosphatase was shown to milder inflammatory response in a murine cecal ligation and puncture (CLP) model of polymicrobial sepsis, lowering the levels of inflammatory cytokines TNF-alpha, interleukin- 6 and macrophage chemoattractant protein 1 and of lung inflammation and liver damage (van Veen et al. 2005, Ebrahimi et al. 2011). Lately, intestinal alkaline phosphatase was shown to prevent the systemic inflammatory response associated with necrotizing enterocolitis in rats (Riggle et al. 2013). The clinical success using calf intestinal AP was demonstrated by 
ongoing clinical trials targeting sepsis in human renal patients, leading to the improvement of their renal function (Heemskerk et al. 2009, Pickkers et al. 2012, Peters et al. 2013, 2014) and in cardiac surgery patients (Kats et al. 2012). Besides the ability of alkaline phosphatase to reduce inflammation through dephosphorylation detoxifying LPS, alkaline phosphatase was shown to convert adenosine triphosphate, released during cellular stress caused by inflammation and hypoxia, into adenosine with anti-inflammatory and tissue-protective effects, thus eliminating its detrimental effects (Peters et al. 2014).

In our study we investigated the potentially therapeutic in vivo effect of the rhTNAP derived from milk of transgenic rabbits (Bodrogi et al. 2006). We received a protein fraction with high activity of rhTNAP and used it for treatment of mice in a LPS-induced model of sepsis. Three hours after LPS administration, mice received by i.v. injection 9 units of rhTNAP which was efficiently taken up by the peripheral blood system, as revealed by the high AP activity in the serum of treated mice. Although the AP activity at $21 \mathrm{~h}$ later decreased to background levels, consistent with rather high AP turnover observed in a model of sepsis induced by $E$. coli infection (Beumer et al. 2003), such treatment was also in our model of LPS-induced sepsis efficient. It is important to note that the lower temperature determined in case of control-treated animals was most probably caused by the fact that the measurement of the temperature of these animals was in fact delayed, due to the spent handling time needed for the intravenous injection of the experimental group with TNAP or with bovine AP. Crucially though, the treatment of the animals (either with TNAP or with bovine AP) contrary to the control situation reverted the decrease in body temperature and significantly increased survival of mice, an effect that was not seen in control-treated animals. Our study also shows that treatment of mice with i.p. injected rhTNAP fraction was effective even after $3 \mathrm{~h}$ of LPS administration.

In summary, our work demonstrates beneficial effects of administration of rhTNAP in a LPS induced model of sepsis. The milk of the transgenic rabbits generated in our laboratory could be the source for large scale production of biologically active rhTNAP supplementing other mammalian phosphatases currently used to treat several inflammatory conditions in patients.

\section{Conflict of Interest}

There is no conflict of interest.

\section{Acknowledgements}

This work was supported by grants from the Hungarian Scientific Research Fund [Grant OTKA T49034] and the Economic 247 Competiveness Operational Program [Grant GVOP-3.1.1.-2004-05-0071/3.0] to Zsuzsanna Bősze.

\section{References}

AHN YS, SNOW LD: Selective extraction of alkaline phosphatase and 5'-nucleotidase from milk fat globule membranes by a single phase n-butanol procedure. Prep Biochem 23: 409-419, 1993.

ANGUS DC, VAN DER POLL T: Severe sepsis and septic shock. N Engl J Med 369: 840-851, 2013.

BENTALA H, VERWEIJ WR, HUIZINGA-VAN DER VLAG A, VAN LOENEN-WEEMAES AM, MEIJER DK, POELSTRA K: Removal of phosphate from lipid A as a strategy to detoxify lipopolysaccharide. Shock 18: 561-566, 2002.

BEUMER C, WULFERINK M, RAABEN W, FIECHTER D, BRANDS R, SEINEN W: Calf intestinal alkaline phosphatase, a novel therapeutic drug for lipopolysaccharide (LPS)-mediated diseases, attenuates LPS toxicity in mice and piglets. J Pharmacol Exp Ther 307: 737-744, 2003.

BODROGI L, BRANDS R, RAABEN W, SEINEN W, BARANYI M, FIECHTER D, BOSZE Z: High level expression of tissue-nonspecific alkaline phosphatase in the milk of transgenic rabbits. Transgenic Res 15: 627-636, 2006.

CYBORON GW, WUTHIER RE: Purification and initial characterization of intrinsic membrane-bound alkaline phosphatase from chicken epiphyseal cartilage. J Biol Chem 256: 7262-7268, 1981.

EBRAHIMI F, MALO MS, ALAM SN, MOSS AK, YAMMINE H, RAMASAMY S, BISWAS B, CHEN KT, MUHAMMAD N, MOSTAFA G, WARREN HS, HOHMANN EL, HODIN RA: Local peritoneal irrigation with intestinal alkaline phosphatase is protective against peritonitis in mice. J Gastrointest Surg 15: 860-869, 2011. 
HEEMSKERK S, MASEREEUW R, MOESKER O, BOUW MP, VAN DER HOEVEN JG, PETERS WH, RUSSEL FG, PICKKERS P; APSEP STUDY GROUP: Alkaline phosphatase treatment improves renal function in severe sepsis or septic shock patients. Crit Care Med 37: 417-423, 2009.

HEINE H, RIETSCHEL ET, ULMER AJ: The biology of endotoxin. Mol Biotechnol 19: 279-296, 2001.

HENTHORN PS, RADUCHA M, FEDDE KN, LAFFERTY MA, WHYTE MP: Different missense mutations at the tissue-nonspecific alkaline phosphatase gene locus in autosomal recessively inherited forms of mild and severe hypophosphatasia. Proc Natl Acad Sci U S A 89: 9924-9928, 1992.

HOSHI K, AMIZUKA N, ODA K, IKEHARA Y, OZAWA H: Immunolocalization of tissue non-specific alkaline phosphatase in mice. Histochem Cell Biol 107: 183-191, 1997.

KATS S, BRANDS R, HAMAD MA, SEINEN W, SCHARNHORST V, WULKAN RW, SCHONBERGER JP, VAN OEVEREN W: Prophylactic treatment with alkaline phosphatase in cardiac surgery induces endogenous alkaline phosphatase release. Int J Artif Organs 35: 144-151, 2012.

KOYAMA I, MATSUNAGA T, HARADA T, HOKARI S, KOMODA T: Alkaline phosphatases reduce toxicity of lipopolysaccharides in vivo and in vitro through dephosphorylation. Clin Biochem 35: 455-461, 2002.

KOZAK W, ZHENG H, CONN CA, SOSZYNSKI D, VAN DER PLOEG LH, KLUGER MJ: Thermal and behavioral effects of lipopolysaccharide and influenza in interleukin-1 beta-deficient mice. Am J Physiol 269: R969-R977, 1995.

LAM SW, BAUER SR, GUZMAN JA: Septic shock: the initial moments and beyond. Cleve Clin J Med 80: 175-184, 2013.

LEVY MM, DELLINGER RP, TOWNSEND SR, LINDE-ZWIRBLE WT, MARSHALL JC, BION J, SCHORR C, ARTIGAS A, RAMSAY G, BEALE R, PARKER MM, GERLACH H, REINHART K, SILVA E, HARVEY M, REGAN S, ANGUS DC; SURVIVING SEPSIS CAMPAIGN: The Surviving Sepsis Campaign: results of an international guideline-based performance improvement program targeting severe sepsis. Crit Care Med 38 : 367-374, 2010.

NARISAWA S, FROHLANDER N, MILLAN JL: Inactivation of two mouse alkaline phosphatase genes and establishment of a model of infantile hypophosphatasia. Dev Dyn 208: 432-446, 1997.

PETERS E, VAN ELSAS A, HEEMSKERK S, JONK L, VAN DER HOEVEN J, AREND J, MASEREEUW R, PICKKERS P: Alkaline phosphatase as a treatment of sepsis-associated acute kidney injury. J Pharmacol Exp Ther 344: 2-7, 2013.

PETERS E, HEEMSKERK S, MASEREEUW R, PICKKERS P: Alkaline phosphatase: a possible treatment for sepsisassociated acute kidney injury in critically ill patients. Am J Kidney Dis 63: 1038-1048, 2014.

PICKKERS P, HEEMSKERK S, SCHOUTEN J, LATERRE PF, VINCENT JL, BEISHUIZEN A, JORENS PG, SPAPEN H, BULITTA M, PETERS WH, VAN DER HOEVEN JG: Alkaline phosphatase for treatment of sepsis-induced acute kidney injury: a prospective randomized double-blind placebo-controlled trial. Crit Care 16: R14, 2012.

POELSTRA K, BAKKER WW, KLOK PA, HARDONK MJ, MEIJER DK: A physiologic function for alkaline phosphatase: endotoxin detoxification. Lab Invest 76: 319-327, $1997 \mathrm{a}$.

POELSTRA K, BAKKER WW, KLOK PA, KAMPS JA, HARDONK MJ, MEIJER DK: Dephosphorylation of endotoxin by alkaline phosphatase in vivo. Am J Pathol 151: 1163-1169, 1997b.

RIEDEMANN NC, GUO RF, WARD PA: Novel strategies for the treatment of sepsis. Nat Med 9: 517-524, 2003.

RIGGLE KM, RENTEA RM, WELAK SR, PRITCHARD KA Jr, OLDHAM KT, GOURLAY DM: Intestinal alkaline phosphatase prevents the systemic inflammatory response associated with necrotizing enterocolitis. J Surg Res 180: 21-26, 2013.

SCHULTE W, BERNHAGEN J, BUCALA R: Cytokines in sepsis: potent immunoregulators and potential therapeutic targets - an updated view. Mediators Inflamm 2013: 165974, 2013.

SU F, BRANDS R, WANG Z, VERDANT C, BRUHN A, CAI Y, RAABEN W, WULFERINK M, VINCENT JL: Beneficial effects of alkaline phosphatase in septic shock. Crit Care Med 34: 2182-2187, 2006.

UHRIN P, PERKMANN T, BINDER B, SCHABBAUER G: ISG12 is a critical modulator of innate immune responses in murine models of sepsis. Immunobiology 218: 1207-1216, 2013. 
VAN VEEN SQ, VAN VLIET AK, WULFERINK M, BRANDS R, BOERMEESTER MA, VAN GULIK TM: Bovine intestinal alkaline phosphatase attenuates the inflammatory response in secondary peritonitis in mice. Infect Immun 73: 4309-4314, 2005.

VERWEIJ WR, BENTALA H, HUIZINGA-VAN DER VLAG A, MIEK VAN LOENEN-WEEMAES A, KOOI K, MEIJER DK, POELSTRA K: Protection against an Escherichia coli-induced sepsis by alkaline phosphatase in mice. Shock 22: 174-179, 2004.

WAYMIRE KG, MAHUREN JD, JAJE JM, GUILARTE TR, COBURN SP, MACGREGOR GR: Mice lacking tissue non-specific alkaline phosphatase die from seizures due to defective metabolism of vitamin B-6. Nat Genet 11: 45-51, 1995. 